\title{
Exchange Rates And Equity Markets: Evidence From Some European Countries
}

\author{
Oana Ariana Batori, Purdue University-Calumet, USA \\ Dimitrios Tsoukalas, Purdue University-Calumet, USA \\ Paolo Miranda, Purdue University-Calumet, USA
}

\begin{abstract}
This paper employs cointegration analysis, vector error correction and vector autoregressive modeling along with Granger causality tests to examine the effect of exchange rates on the stock market indexes for a group of European Union countries using daily data from 1999-2009. The results suggest that the transmitting mechanism for the influence of the exchange rate in the stock market is foreign investment. Evidence also highlights that there is no clear causality from stock market to exchange rates, or vice versa, for the direction of the causation, suggesting that exchange rates and stock markets operate as an integrated system continuously influencing each other.
\end{abstract}

Keywords: Exchange rates, equity markets, co-integration, Vector Error Correction, Granger Causality

\section{INTRODUCTION}

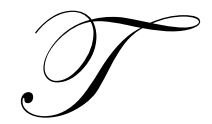

he increased financial liberalization observed since the 1980's (Bekaert and Harvey, 1995) rises the questions of whether exchange rates influence stock prices, in what direction, and by which mechanism. According to the Sharpe, Lintner, Mossin Capital Asset Pricing Model (CAPM), only the systematic risk is priced in an efficient, arbitrage-free market; hence, the implication of the CAPM is that in a globally integrated efficient and arbitrage-free market, exchange rates should have no influence on stock prices unless they can be considered systematic risk. Adler and Dumas (1983) present a model based on Solnik (1974), where they show that if Purchasing Power Parity does not hold across countries, the exchange rate risk would be non diversifiable and will have influence over the stock market index price. The reason is that if Purchasing Power Parity does not hold, investors in different countries will see different efficient frontiers, implying no agreement on the market portfolio, hence different valuations. The influence of exchange rates on stock prices can also stem from the fact that a devalued currency increases the exports of a country until the demand for the currency pushes its price up, equalizing prices of tradable goods across the board. It might be surmised that the exporting companies in a country like such will see their valuation increase, at least during periods of exporting bonanza. It can be then suggested that the stock market index value for net exporting countries increases when the home currency depreciate. The story expressed in the last paragraph assumes that there is no substantial financial trading across countries and that the exporting firms drive the stock market. Because a depreciated currency makes the securities of a country less attractive to foreigners, if foreigners trade heavily in the home country, a depreciated currency is expected to impact negatively the stock market index. Also, if the exporting companies do not drive the market, we cannot claim that a depreciated currency will increase the value of the stock market index.

\section{LITERATURE REVIEW}

Several authors have concerned themselves on whether exchange rates have influence on stock prices, among them Ajayi and Mougoue (1996) who, applying a vector error correction model, find significant short and long run interrelations between exchange rates and stock indices. De Santis and Gerard (1998) use a GARCH model and study the markets of Germany, the U.K., Japan, and the U.S.; they find support for the currency risk being priced. Mao and Kao (1990) find that for net exporting economies the stock prices react negatively to currency appreciation, the opposite is found for net importing economies. Wu (2000) using cointegration and error correction 
analyses, shows that appreciation in exchange rates have long term positive effects in the stock prices in Singapore during four different periods of the 1990's. Granger, Huang, and Yang (2000) study the causal relation between stock prices and exchange rates for seven Asian countries affected by the Asian flu, their results are mixed, finding that exchange rates lead stock prices for two of the countries, stock prices lead exchange rate for one country and what they call "strong feedback" for the four remaining countries. Dominguez and Tesar (2001), using a CAPM type OLS regression, and a sample of firms in eight countries over an eighteen year period find that firm level and industry level share prices are influenced by exchange rates. Stavarek (2004) uses a Vector Error Correction model to study the relationship between exchange rate and stock returns for eight European countries and the United States between the years 1969-1992, he finds no relationship between these variables for most of the years and countries involved. Yang and Doong (2004) with an EGARCH model show that movements in stock prices will affect future exchange rate movements, but exchange rates have less direct impact on future changes of stock prices in the G-7 countries. Dimitrova (2005) uses a 2SLS model to study the relationship between exchange rates and stock prices; using data for the U.S. and the U.K. she finds that a depreciation of the currency depresses the stock market. Phylaktis and Ravazzolo (2005) in a study of the long term dynamics between stock prices and exchange rates using cointegration and multivariate Granger causality tests, show that for a group of Pacific Basin countries foreign exchange and stock markets are positively related from 1980-1998. Shew (2008), analyzing Singapore data from 1990-2006, using Granger causality tests shows no relationship between stock prices and exchange rates for the whole period, causality from exchange rates to stock prices from 1990-2001 and causality from stock to exchange rates from 2002-2006. Kumar (2010) applies linear and non-linear Granger causality models to examine the relationship for India to show that both tests reveal evidence of bi-directional causality between stock prices and exchange rates. Alagidede, Pnagiotis and Zhang (2010) examines the stock and exchange rates markets with cointegration and Granger tests to show that exchange rates Granger cause the stock prices of Canada, Switzerland and the U.K..

\section{THEORETICAL BACKGROUND}

To fix the ideas, in the spirit of Backus, Foresi, and Telmer (2001) we present an equation based on the first order conditions of a representative consumer that receives an endowment each period, invests a proportion of his wealth in his home country and the rest in a foreign country. His consumption at any time is determined by its endowment plus the payoffs from previous investments minus the cost of new investments. The assets are priced by a stochastic discount factor that reflects the change in the marginal utility of consumption in the corresponding market. Once the first order conditions have been solved for the representative investor at home and abroad, we obtain the following relation between the stochastic discount factors at home and abroad:

$m_{t+k, h}=m_{t+k, f} \frac{1+\pi_{t+k, h}}{1+\pi_{t+k, f}} \frac{1}{1+r e_{t+k}}$

Where the stochastic discount factors at home and abroad at time $\mathrm{t}+\mathrm{k}$ are denoted by $\mathrm{m}_{\mathrm{t}+\mathrm{k}, \mathrm{h}}$ and $\mathrm{m}_{\mathrm{t}+\mathrm{k}, \mathrm{f}}$ respectively, the inflation rate at home and abroad are denoted by $\pi_{\mathrm{t}+\mathrm{k}, \mathrm{h}}$ and $\pi_{\mathrm{t}+\mathrm{k}, \mathrm{f}}$ respectively, and the fractional change in exchange rates are denoted by $\mathrm{re}_{\mathrm{t}+\mathrm{k}}$. Since the exchange rates are presented as units of home currency per United States dollar, an appreciation of the home currency shows as a negative value for $\mathrm{re}_{\mathrm{t}+\mathrm{k}}$. The derivation of Equation (1) is presented in the appendix. The price of any asset both in the home and the foreign country can be expressed at any point in time as $\mathrm{p}=\mathrm{E}(\mathrm{mx})$ where $\mathrm{x}$ is the payoff given by the asset and $\mathrm{m}$ is the corresponding stochastic discount factor, from this simple expression plus Equation (1) we can obtain some conclusions that will help evaluate the empirical results. First, we can see how an increase in the exchange rate, corresponding to a depreciation of the home currency with respect to the United States dollar, lowers the home stochastic discount factor, lowering the price of the stocks at home. Second, we can also see that increased foreign inflation rate decrease the price of stocks at home. It has to be considered that the stochastic discount factors represent the change in the marginal utility of consumption, suggesting that relative consumption between the home and foreign markets will affect the relative prices of the stock indexes. For example, if there is a sudden increase of consumption in the foreign country at $\mathrm{t}=0$, the marginal utility of consumption decrease, increasing the stochastic discount factor and the price of stocks in the home country. In accordance with the model posited by Adler and Dumas (1983), we can see in Equation (1) that if Purchasing Power Parity holds, even in its relative form, the stochastic discount factors between the home and foreign country will move in unison, and the price of stocks in the home country will be 
independent of the exchange rate. Also, consumption will depend on the exchange rates through the price of imports, suggesting that the effect of the exchange rate on stock prices stems from a complex set of interactions whose final result will depend on the particular country. The reasoning presented in the last paragraph could explain the dispersion in the results found in the studies that deal with the relation between the exchange rates and stock prices. Based on Equation (1) we expect an appreciation of the home country currency with respect to the dollar to increase the value of the home index, this occurs because an appreciation of the home currency is reflected in less units of home currency per United States dollar. Conversely, if the change in the exchange rate level is positive, the currency depreciates and the index value lowers. Hence, in the regressions a positive impulse for the exchange rate should lower the value of the index, we then expect the coefficient for exchange rate to be negative.

\section{ECONOMETRIC METHODOLOGY AND RESULTS}

We use daily data for exchange rates and stock market index returns for the Czech Republic, Denmark, Hungary, Poland, Romania, Sweden, and the U.K., the years range from 1999 to 2009 for all the countries with the exception of Denmark, whose series are from 2000 to 2009, and Sweden whose series range from 2001 to 2009.

We first test for unit roots in log levels and in differences by using the augmented Dickey-Fuller test to ascertain whether the series are integrated of order zero, one, or higher. Once the integration order of a series is known, we use the Johansen cointegration test to ascertain the existence of cointegrated series. The information about unit roots and cointegration is used to decide if the best model to be used for estimation is a Vector Auto Regressive model (VAR) or a Vector Error Correction Model (VEC).

The Augmented Dickey Fuller test shows that the log level of stock indexes for all the markets in this study have unit roots; the test for the exchange rate shows that, at the 5\% level, only Romania and Hungary do not have unit roots. Also, the Dickey fuller test shows that the index series are I(1) in levels, as are most of the exchange rate series. After we have used the Dickey Fuller test to ascertain the existence of unit roots, we use the Johansen test for cointegration. The Johansen test, also called the trace test, is based on the likelihood ratio and asks whether the rank of the cointegrated matrix is between zero and the number of variables used in the model, the closer the rank is to the number of variables used, the less is the number of cointegrated variables. Table 1 presents the results based on the Johansen (1995) cointegration test, the critical values are taken from the same source.

The results of Table 1 suggest that exchange rates and indexes are cointegrated in levels for all countries except Poland and Romania, making the use of VEC models in levels appropriate since the use of VAR models in differences in cointegrated series looses the long run interaction between the cointegrated variables, being akin to an omitted variable bias. For Poland and Romania, we use a VAR model in differences, since the use of VEC models in levels for no cointegrated variables that are I(1) could lead to unreliable results.

Table 1: Co-integration tests

\begin{tabular}{|l|c|c|c|}
\hline & trace statistic & rank & 5\% critical value \\
\hline Czech republic & 5.74 & 0 & 15.41 \\
\hline Denmark & 15.16 & 0 & 15.41 \\
\hline Hungary & 9.31 & 0 & 15.41 \\
\hline Poland & 19.93 & 2 & 15.41 \\
\hline Romania & 21.43 & 2 & 15.41 \\
\hline Sweden & 5.14 & 0 & 15.41 \\
\hline United Kingdom & 5.07 & 0 & 15.41 \\
\hline
\end{tabular}

The $5 \%$ value for the test is 15.41 for a rank zero. Rank correspond to the rank of the cointegrated matrix

The number of lags to be used for the VEC and VAR models is determined by maximizing the Akaike Information Criteria. The VEC model to be fit for the majority of the countries considered, Poland and Romania being the exception, is of the form

$\Delta Y_{t}=\Pi Y_{t-1}+\Gamma \Delta Y_{t-1}+\mu$ 
Where $Y_{t}$ is a $\mathrm{kp} x 1$ vector, $\mathrm{k}$ being the number of indices with $\mathrm{p}$ being the number of lags, $\Pi$ is a $\mathrm{k} \mathrm{x} \mathrm{k}$ matrix representing the long run relation between the variables, $\Gamma$ is a $\mathrm{k} \mathrm{kp}$ matrix representing the short term relationship between the variables, and $\mu$ is a $\mathrm{kp} \mathrm{x} 1$ vector of white noise. The results for this model are presented in Table 2. From the table, we can see that the exchange rate influences the index value for most of the countries in the short term, the only exceptions are Sweden and Romania for which the exchange rate coefficients are statistically insignificant. Having the exchange rate influencing the index suggest that exchange rate is a no diversifiable risk, in agreement with the model posited by Adler and Dumas (1983). We also observe that the coefficients for the exchange rate are mostly negative when the index is the dependent variable, suggesting that if the exchange rate depreciates, the index level is lower (hence, its return). This is consistent with Equation 1, suggesting that the index might be in part driven by foreign investment, also, the index losing value when the currency depreciates is consistent with net importing countries. The results presented in Table 2 show that increases in the value of the index are mostly associated with an appreciation of the currency, suggesting that foreign portfolio investment might have a non negligible effect on the index. The long run relationship between the variables estimated by VEC models is measured by the coefficient beta, which gives the linear relationship that makes the variables $\mathrm{I}(0)$ in levels, the beta coefficient is presented in Table 3. Consistent with the short term results, most of the long term coefficients are negative, with the exception of the U.K. and Czech Republic. A negative coefficient suggests that in the long run, the home stock market index decreases in value when the currency of the country depreciates with respect to the United States dollar; which is what we expected based on Equation (1). The results suggest for the Czech Republic, in the short term, a decrease in the stock market index value when the currency depreciates; while in the long term the results suggest that a depreciation of the currency increases the stock market index value. As stated before, for a net exporter country whose exporting sector drives the market, it is expected a positive relation between depreciation and index value. For Romania and Poland, we used a VAR model in differences because the variables for those countries are not cointegrated.

For Romania, we find that a positive shock to the difference in exchange rates provokes an increase in the difference of the index, this amount to saying that an increased depreciation of the home currency increases the value of the home index. The result for Romania is contrary to what was found for most of the countries, except England, and to what is expected based on equation (1), where we expect a depreciation to decrease the value of the home index. For Poland, we find that an increase in the exchange rate difference decreases the home index value, depreciation of the currency decreases the value of the index, as expected according to Equation (1). As stated before, there are two possible views of the relation between stock market index and exchange rate; the first is based on foreign investment, reflected in Equation (1), where the depreciation of the currency entails a lowering of the stock market index value. The second view is based on the assumption that a net exporting country whose market is driven by the export industry will have an increase in the stock market index value when the currency depreciates. We find that for seven of the countries studied the stock market index value decreases when the home currency depreciates, suggesting foreign investment to be more important than the country being a net importer or exporter in the determination of the stock market value. To assess whether the importance of a country being a net exporter, or importer we calculate the ratio of exports to imports, using data from the United Nations Statistical database covering the years 1970 to 2008 , and test the hypothesis of the ratio being statistically different than 1 . The data and the results of the test are presented in Table 4.

From Table 4, we can see that we can reject, at the 5\% level, the null of the ratio exports/imports equal to one for Denmark and Sweden, while at the $10 \%$ level, we add Poland. For Denmark and Sweden, we cannot reject, at the 5\% level, the null of more exports than imports. Despite this fact, the results of the VEC model for these countries suggest that a depreciation of the currency lowers the value of the stock market index. At the 10\% confidence level, we cannot reject the null of net exporters for Denmark, Sweden, and the Czech Republic, we also cannot reject the null of net importers for Hungary, Poland, and the U.K. The results show that, regardless of the countries being net importers or exporters, a depreciation implies lower value of the stock market index, suggesting that foreign investment is a more important determinant of the influence of exchange rate in the stock market than the country being a net exporter or importer. 
Table 2: results of the VEC and VAR models

\begin{tabular}{|c|c|c|c|c|c|c|c|c|c|c|c|c|c|c|}
\hline & $\begin{array}{l}\text { Czech } \\
\text { index }\end{array}$ & $\begin{array}{l}\text { Czech } \\
\text { exch. }\end{array}$ & $\begin{array}{l}\text { Denmark } \\
\text { index }\end{array}$ & $\begin{array}{c}\text { Denmark } \\
\text { exch. }\end{array}$ & $\begin{array}{c}\text { Hungary } \\
\text { index }\end{array}$ & $\begin{array}{c}\text { Hungary } \\
\text { exch. }\end{array}$ & $\begin{array}{c}\text { Sweden } \\
\text { index }\end{array}$ & $\begin{array}{l}\text { sweden } \\
\text { exch. }\end{array}$ & $\begin{array}{c}\text { U.K. } \\
\text { index }\end{array}$ & $\begin{array}{l}\text { U.K. } \\
\text { exch. }\end{array}$ & $\begin{array}{c}\text { Romania } \\
\text { dfindex }\end{array}$ & $\begin{array}{l}\text { Romania } \\
\text { dfexch. }\end{array}$ & $\begin{array}{l}\text { Poland } \\
\text { dfindex }\end{array}$ & $\begin{array}{l}\text { Poland } \\
\text { dfexch. }\end{array}$ \\
\hline index $t-1$ & $\begin{array}{l}-0.074 \\
(-4.66) \\
\end{array}$ & $\begin{array}{l}-0.004 \\
(-1.12) \\
\end{array}$ & $\begin{array}{l}-0.051 \\
(-3.09) \\
\end{array}$ & $\begin{array}{c}0.00007 \\
(0.36) \\
\end{array}$ & $\begin{array}{l}-0.067 \\
(-4.03) \\
\end{array}$ & $\begin{array}{l}-0.022 \\
(-4.03) \\
\end{array}$ & $\begin{array}{l}-0.078 \\
(-4.31) \\
\end{array}$ & $\begin{array}{l}-0.032 \\
(-6.30) \\
\end{array}$ & $\begin{array}{l}-0.151 \\
(-9.51) \\
\end{array}$ & $\begin{array}{l}-0.002 \\
(-0.42) \\
\end{array}$ & $\begin{array}{l}0.015 \\
(0.96) \\
\end{array}$ & $\begin{array}{l}0.011 \\
(1.88) \\
\end{array}$ & $\begin{array}{l}-0.102 \\
(-6.10) \\
\end{array}$ & $\begin{array}{l}-0.023 \\
(-3.48) \\
\end{array}$ \\
\hline index t-2 & $\begin{array}{l}0.012 \\
(0.76)\end{array}$ & $\begin{array}{l}0.018 \\
(4.17)\end{array}$ & $\begin{array}{l}-0.009 \\
(-0.57)\end{array}$ & $\begin{array}{c}-0.0004 \\
(-0.26)\end{array}$ & $\begin{array}{l}-0.021 \\
(-1.24)\end{array}$ & $\begin{array}{l}0.011 \\
(1.96)\end{array}$ & $\begin{array}{l}-0.014 \\
(-0.77)\end{array}$ & $\begin{array}{l}0.021 \\
(4.18)\end{array}$ & $\begin{array}{c}-0.07 \\
(-0.46)\end{array}$ & $\begin{array}{l}-0.002 \\
(-0.29)\end{array}$ & $\begin{array}{l}-0.017 \\
(-1.08)\end{array}$ & $\begin{array}{l}0.002 \\
(0.38)\end{array}$ & $\begin{array}{l}0.014 \\
(0.88)\end{array}$ & $\begin{array}{l}0.002 \\
(0.24)\end{array}$ \\
\hline index t-3 & $\begin{array}{l}0.005 \\
(0.33) \\
\end{array}$ & $\begin{array}{l}0.009 \\
(2.07) \\
\end{array}$ & $\begin{array}{l}0.019 \\
(1.15) \\
\end{array}$ & $\begin{array}{c}0 \\
(0.04) \\
\end{array}$ & $\begin{array}{l}0.041 \\
(2.46) \\
\end{array}$ & $\begin{array}{l}0.004 \\
(0.71) \\
\end{array}$ & $\begin{array}{l}0.021 \\
(1.12) \\
\end{array}$ & $\begin{array}{l}-0.03 \\
(0.53) \\
\end{array}$ & & & $\begin{array}{l}0.084 \\
(5.32) \\
\end{array}$ & $\begin{array}{l}0.012 \\
(1.96) \\
\end{array}$ & $\begin{array}{l}0.054 \\
(3.24) \\
\end{array}$ & $\begin{array}{l}-0.018 \\
(-0.80) \\
\end{array}$ \\
\hline index $t-4$ & $\begin{array}{l}-0.021 \\
(-1.30) \\
\end{array}$ & $\begin{array}{c}0.0003 \\
(0.07)\end{array}$ & $\begin{array}{l}0.015 \\
(0.91) \\
\end{array}$ & $\begin{array}{l}0.001 \\
(0.84)\end{array}$ & $\begin{array}{l}-0.024 \\
(-1.47) \\
\end{array}$ & $\begin{array}{l}0.007 \\
(1.35)\end{array}$ & $\begin{array}{l}-0.009 \\
(-0.49) \\
\end{array}$ & $\begin{array}{l}0.007 \\
(1.30)\end{array}$ & & & $\begin{array}{l}0.031 \\
(1.93)\end{array}$ & $\begin{array}{l}-0.012 \\
(-2.00) \\
\end{array}$ & & \\
\hline ex t-1 & $\begin{array}{l}-0.182 \\
(-3.06)\end{array}$ & $\begin{array}{l}-0.130 \\
(-8.18)\end{array}$ & $\begin{array}{l}-3.008 \\
(2.04)\end{array}$ & $\begin{array}{l}-0.063 \\
(-3.83)\end{array}$ & $\begin{array}{l}-0.202 \\
(-2.98)\end{array}$ & $\begin{array}{l}-0.116 \\
(-7.00)\end{array}$ & $\begin{array}{l}-0.041 \\
(-0.62)\end{array}$ & $\begin{array}{l}-0.141 \\
(-7.74)\end{array}$ & $\begin{array}{l}0.081 \\
(2.81)\end{array}$ & $\begin{array}{l}-0.051 \\
(-3.20)\end{array}$ & $\begin{array}{l}0.023 \\
(0.57)\end{array}$ & $\begin{array}{l}-0.072 \\
(-4.55)\end{array}$ & $\begin{array}{l}-0.106 \\
(-2.52)\end{array}$ & $\begin{array}{l}-0.100 \\
(-5.98)\end{array}$ \\
\hline ex t-2 & $\begin{array}{l}-0.186 \\
(3.09) \\
\end{array}$ & $\begin{array}{l}0.021 \\
(1.31) \\
\end{array}$ & $\begin{array}{l}1.402 \\
(0.95) \\
\end{array}$ & $\begin{array}{l}0.017 \\
(1.00) \\
\end{array}$ & $\begin{array}{l}-0.084 \\
(-1.65) \\
\end{array}$ & $\begin{array}{l}0.002 \\
(0.14) \\
\end{array}$ & $\begin{array}{l}0.015 \\
(0.23) \\
\end{array}$ & $\begin{array}{l}0.021 \\
(1.11) \\
\end{array}$ & $\begin{array}{l}0.004 \\
(0.09) \\
\end{array}$ & $\begin{array}{l}0.004 \\
(0.29) \\
\end{array}$ & $\begin{array}{c}-0.003 \\
(-0.007) \\
\end{array}$ & $\begin{array}{l}-0.073 \\
(-4.61) \\
\end{array}$ & $\begin{array}{l}-0.013 \\
(-0.30) \\
\end{array}$ & $\begin{array}{l}-0.026 \\
(-1.57) \\
\end{array}$ \\
\hline ex $t-3$ & $\begin{array}{l}0.056 \\
(0.93)\end{array}$ & $\begin{array}{l}0.032 \\
(2.01)\end{array}$ & $\begin{array}{l}-3.803 \\
(-2.58)\end{array}$ & $\begin{array}{l}0.054 \\
(3.25)\end{array}$ & $\begin{array}{l}0.053 \\
(1.04)\end{array}$ & $\begin{array}{c}0.03 \\
(1.80)\end{array}$ & $\begin{array}{l}0.039 \\
(0.59)\end{array}$ & $\begin{array}{c}0.04 \\
(2.19)\end{array}$ & & & $\begin{array}{l}-0.038 \\
(0.93)\end{array}$ & $\begin{array}{l}0.046 \\
(2.93)\end{array}$ & $\begin{array}{l}0.047 \\
(1.12)\end{array}$ & $\begin{array}{l}0.002 \\
(0.15)\end{array}$ \\
\hline ex $t-4$ & $\begin{array}{l}-0.009 \\
(-0.17)\end{array}$ & $\begin{array}{l}0.023 \\
(1.45)\end{array}$ & $\begin{array}{l}-1.509 \\
(-1.02)\end{array}$ & $\begin{array}{l}0.045 \\
(2.69)\end{array}$ & $\begin{array}{l}-0.048 \\
(-0.94)\end{array}$ & $\begin{array}{c}-0.00001 \\
(0.00)\end{array}$ & $\begin{array}{l}0.069 \\
(1.06)\end{array}$ & $\begin{array}{l}-0.012 \\
(-0.67)\end{array}$ & & & $\begin{array}{l}-0.019 \\
(-0.47)\end{array}$ & $\begin{array}{l}-0.033 \\
(-2.06)\end{array}$ & & \\
\hline R squared & 0.0108 & 0.0247 & 0.007 & 0.0127 & 0.01 & 0.018 & 0.0083 & 0.037 & 0.025 & 0.003 & 0.009 & 0.018 & 0.011 & 0.011 \\
\hline
\end{tabular}

The results refer to the VEC model results for Czech Republic, Denmark, Hungary, Sweden, and the U.K. The VAR results presented correspond to Poland and Romania. Index t-j correspond to the jth lag of the difference in the log index, ext $t$-j corresponds to the jth lag of the first difference in the log exchange rate. T-statistics in parentheses. Index stands for the stock market index of the country considered and exch. stands for the exchange rate. 
Table 3: Long run coefficients

\begin{tabular}{|l|c|c|}
\hline & beta & t \\
\hline Czech republic & 4.88 & 3.25 \\
\hline Denmark & -210.22 & -5.43 \\
\hline Hungary & -42.75 & -2.92 \\
\hline Sweden & -10.63 & -1.96 \\
\hline United Kingdom & 0.014 & 0.02 \\
\hline
\end{tabular}

Table 4: Ratio of exports to imports

\begin{tabular}{|l|c|c|c|c|c|c|c|}
\hline & Czech & Denmark & Hungary & Poland & Romania & Sweden & U.K. \\
\hline average & 1.045 & 1.050 & 0.971 & 0.967 & 0.952 & 1.114 & 0.974 \\
\hline std & 0.135 & 0.087 & 0.124 & 0.108 & 0.278 & 0.151 & 0.098 \\
\hline n & 19 & 38 & 38 & 38 & 38 & 38 & 38 \\
\hline t stat & 1.451 & 3.522 & -1.433 & -1.854 & -1.072 & 4.660 & -1.644 \\
\hline t stat, 1 tail & 1.734 & 1.687 & 1.687 & 1.687 & 1.687 & 1.687 & 1.687 \\
\hline t-stat, 2 tails & 2.101 & 2.026 & 2.026 & 2.026 & 2.026 & 2.026 & 2.026 \\
\hline
\end{tabular}

The ratio of exports to imports, both expressed in United States dollars, mu refers to the ratio exports/imports, $\mathrm{n}$ refers to the number of observations, the degrees of freedom are $\mathrm{n}-1$ for all tests. The $5 \%$ confidence level $\mathrm{t}$-stat for the test mu $=1 \mathrm{is}$ presented in "t-stat, 2 tails", and for the test $m u>1$ is presented in "t-stat, 1 tail".

Table 5: Average and standard deviation of the levels

\begin{tabular}{|l|c|c|c|c|c|}
\hline & \multicolumn{2}{|c|}{ log of index level } & \multicolumn{2}{c|}{ log of exchange rate level } & \\
\hline & average & std & average & std & stdlind/stdlex \\
\hline Checkoslovakia & 6.678 & 0.531 & 3.42 & 0.119 & 4.46 \\
\hline Denmark & 5.74 & 0.254 & 2.01 & 0.001 & 254.00 \\
\hline Hungary & 9.41 & 0.5 & 5.54 & 0.046 & 10.87 \\
\hline Poland & 7.54 & 0.357 & 1.38 & 0.085 & 4.20 \\
\hline Romania & 7.72 & 1.06 & 1.13 & 0.29 & 3.66 \\
\hline Sweden & 5.5 & 0.28 & 2.24 & 0.049 & 5.71 \\
\hline U.K. & 8.56 & 0.19 & -0.37 & 0.1 & 1.90 \\
\hline
\end{tabular}

The series are the daily natural logarithm levels for the stock market indexes and the exchange rates for the countries considered. The ratio stdlind/stdlex is the ratio of the standard deviation of the log of index levels divided by the standard deviation of the log of exchange rate levels. Std stands for standard deviation

Table 6: Granger causality test

\begin{tabular}{|l|c|c|c|}
\hline & dependent & chi^2 & p-value \\
\hline czech republic & lind & 18.23 & 0.004 \\
\hline Denmark & lex & 22.46 & 0.0001 \\
\hline & lind & 12.54 & 0.0057 \\
\hline Hungary & lex & 0.21 & 0.976 \\
\hline & lind & 18.59 & 0.0003 \\
\hline Poland & lex & 21.99 & 0.0001 \\
\hline Romania & dflind & 9.41 & 0.051 \\
\hline & dfex & 17.18 & 0.002 \\
\hline Sweden & dflind & 1.21 & 0.87 \\
\hline & dfex & 10.96 & 0.027 \\
\hline United Kingdom & lind & 0.78 & 0.854 \\
\hline & lex & 64.74 & 0 \\
\hline
\end{tabular}

Lind is the log level of the index, lex is the log of the exchange rate, dflind is the first difference of the log level of the index and dfex is the first difference of the log of the exchange rate 
We can also see in Table 2 that the overall fit of the model is rather low, with the best model being able to explain only $3.7 \%$ of the variation in the dependent variable. A possible reason for such result is the difference in volatility between the series, with the exchange rate series being much less volatile than the index series, even when logarithms are taken, we have a low variability series explaining a high variability series, leading to a low $\mathrm{R}$ squared. Table 5 presents the averages, standard deviations and ratios for the log level indexes and the log level exchange rates.

We perform Granger causality tests for the countries used in this study. The results are shown in Table 6.

In accordance with previous literature, the results are not consistent across countries. For the Czech Republic, Hungary, and Poland the Granger tests suggest that exchange rates cause changes in the stock market and the stock market causes changes in the exchange rates, causality goes both ways for these markets. For Denmark we obtain that exchange rates cause changes in the index price, but the index price does not cause changes in the exchange rate. For Romania and Sweden, we find that the exchange rate does not cause changes in the index price but the index price causes changes in the exchange rate. For the U.K. we find that exchange rate and index price do not influence each other..

\section{CONCLUSION}

We studied the effect of exchange rates on the stock market indexes for seven countries using both Vector Error Correction and Vector Auto Regression models, the model being decided based on whether cointegration was present or not. The results from both models are consistent with the level of foreign investment affecting the stock market through exchange rates, this based on the sign of the change in the stock market given a change in the currency value. The results also suggest that a country being a net exporter does not imply that a depreciated currency will boost its stock market. To the contrary, we find that for most of the countries, a depreciated currency depresses the stock market, which can be interpreted as foreign investment having a stronger effect on the stock market than exporting firms. The Granger causality tests indicate that there is no clear causality from stock market to exchange rates, or vice versa, suggesting that exchange rates and stock markets operate as an integrated system continuously influencing each other.

\section{AUTHOR INFORMATION}

Oana Ariana Batori: graduate student at Purdue University-Calumet. She is pursuing her MBA degree with emphasis in Finance and Banking. She is a supplementary Instructor in Econometrics and Macroeconomics and research assistant at the School of Management. She has research publications in refereed journals.

Dimitrios Tsoukalas: Professor of Economics/Finance. He teaches Finance, econometrics, Statistics for the MBA, Real Estate Finance, Money and Banking and Macroeconomics. Pr. Tsoukalas has numerous publications in Financial and Economics refereed journals.

Paolo Miranda: Assistant professor of Finance. Pr Miranda teaches Finance at the graduate and undergraduate level. His research is published in many refereed financial and economics journals.

\section{BIBLIOGRAPHY}

1. Adler, Michael and Bernard Dumas, 1983, "International portfolio choice and corporation finance: A synthesis", The Journal of Finance, 38, pp 925-959.

2. Alagidede P., Pnagiotis T., and Zhang X., 2010, "Causal Relationship between Stock Prices and Exchange Rates: Stirling Economics Discussion paper 2010-05 February, 2010.

3. Backus, D, Silverio Foresi, and Chris Telmer, 2001, "Affine term structure models and the forward premium anomaly", The Journal of Finance, 279-304.

4. Bekaert G. and Campbell Harvey, 1995, "Time varying world market integration", The Journal of Finance, 403-444. 
5. De Santis, Giorgio and Bruno Gerard, 1998, "How big is the premium for currency risk?", Journal of Financial Economics, 49, pp 375-412.

6. Desislava, D., 2005, "The relationship between exchange rates and stock prices: Studied in a multivariate model", Issues in Political Economy 14, pp 1-25

7. Dominguez, Kathryn and Linda Tesar, 2001, "A re examination of exchange rate exposure", American Economic Review, Vol. 91, No. 2, Papers and Proceedings, 396-399, May 2001.

8. Granger, C.W., Huang, B., Yang, C.W., 2000, "A bivariate causality between stock prices and exchange rates: Evidence from recent Asian flu". The Quarterly Review of Economics and Finance 40, pp 337-354

9. Johansen, 1995, "Likelihood Based Inference in Cointegrated Vector Autoregressive Models", Oxford, Oxford University Press.

10. Kumar, M., 2010, "Causal Relationship Between Stock Price and Exchange Rate: Evidence from India", International Journal of Economic Policy in Emerging Economies, 2010, Vol. 3, No.1, pp. 85-101.

11. Lintner, J, 1965, "Security prices, risk, and maximal gains from diversification", Journal of Finance, December 1965, pp 587-615.

12. Mao C.K. and G.W. Cao, 1990, "On exchange rates and stock price reactions", Journal of Business, Finance, and Accounting, 17, 441-449.

13. Mossin, J., 1966, Equilibrium in a capital asset market, Econometrica, October 1966, pp 768-783.

14. Phylaktis K., and Ravazzolo F.(2005), "Stock Prices and Exchange Rate Dynamics", Journal of Money and Finance 24, 2005, pp1031-1053.

15. Sharpe, W.F., 1964, "Capital asset prices: A theory of market equilibrium under conditions of risk", The Journal of Finance 19, pp 425-442

16. Solnik, Bruno, 1974, "An equilibrium model of the international capital market”, Journal of Economic Theory, 8, pp 500-524.

17. Shew, J. A., 2008, "Causality Relationship between Foreign Exchange Rates and Stock Market Close: Evidence in Singapore", Brayant Economic Research paper Vol. 1, No. 11, 2008.

18. Yang, S.-Y., and Doong, S-C, "Price and Volatility Spillovers between Stock Prices and Exchange Rates: Empirical Evidence from the G-7 Countries", International Journal of Business and Economics, 2004, Vol. 3, No.2, pp139-153.

19. Wu Ying, 2000, "Stock Prices and Exchange Rates in a VEC Model-The Case of Singapore in the 1990s" Journal of Economics and Finance, Vol. 24, No 3, pp 260-274.

20. Stavarek, Daniel, 2004, "Stock prices and exchange rates in the EU and the USA: Evidence of their mutual interactions", MPRA paper 7297. 


\section{APPENDIX}

Suppose a representative investor at home who receives an endowment $\mathrm{w}_{\mathrm{t}}$ at period $\mathrm{t}$, and buys $\xi_{\mathrm{ht}}$ shares of the home index and $\xi_{\mathrm{ft}}$ shares of the foreign index at time t. The price levels at home and abroad are represented by $\mathrm{q}_{\mathrm{ht}}$ and $\mathrm{q}_{\mathrm{ft}}$ respectively while the price of one share of the index at home and abroad are represented by $\mathrm{p}_{\mathrm{ht}}$ and $\mathrm{p}_{\mathrm{ft}}$ respectively while the exchange rate at time $t$ is represented by $e_{t}$, it is understood that the exchange rate is in direct quote, that is units of home currency / units of foreign currency.

The representative investor at home maximizes the expected utility of consumption at $t=0$, that is, he maximizes the function:

$U_{h}=U\left(c_{t}\right)+E_{t}\left[\sum_{i=1}^{k} \beta^{i} U\left(c_{t+i}\right)\right]$

Subject to the following restrictions:

The real consumption at time t equals the endowment minus the investment in assets at home and abroad, all divided by the price level.

$c_{t}=\frac{1}{q_{h t}}\left[w_{t}-\xi_{h t} p_{h t}-\xi_{f t} p_{f t} e_{t}\right]$

The real consumption at time $\mathrm{t}+\mathrm{j}, \mathrm{j}$ in $[1, \mathrm{k}]$ is given by,

$c_{t+j}=\frac{1}{q_{h, t+j}}\left[w_{t+j}+\xi_{h, t+j-1} p_{h, t+j}+\xi_{f, t+j-1} p_{f, t+j} e_{t+j}-\xi_{h, t+j} p_{h, t+j}-\xi_{f, t+j} p_{f, t+j} e_{t+j}\right]$

At $t+k$, the last period, the investor receive the payoffs from the securities, hence, his consumption is

$c_{t+k}=\frac{1}{q_{h, t+k}}\left[w_{t+k}+\xi_{h, t+k-1} x_{h, t+k}+\xi_{f, t+k-1} x_{f, t+k} e_{t+k}\right]$

Taking the first order condition of the utility function with respect to the number of shares abroad and the number of shares in the home market and solving for the prices we get, for all periods before $\mathrm{t}=\mathrm{k}$, for the price of home index:

$p_{h, t+j}=E\left[\beta \frac{U^{\prime}\left(c_{t+j+1}\right)}{U^{\prime}\left(c_{t+j}\right)} \frac{q_{t+j}}{q_{t+j+1}} p_{h, t+j+1}\right]$

While, using the condition for the last period, we get for the price of home assets

$p_{h, t+k-1}=E\left[\beta \frac{U^{\prime}\left(c_{t+j+1}\right)}{U^{\prime}\left(c_{t+j}\right)} \frac{q_{h, t+j}}{q_{h, t+j+1}} x_{h, t+k}\right]$

We do an equivalent procedure for an investor in the foreign country and we obtain for the price of the home asset from the perspective of a foreigner:

$p_{h, t+j}=E\left[\beta \frac{U_{f}^{\prime}\left(c_{t+j+1}\right)}{U_{f}^{\prime}\left(c_{t+j}\right)} \frac{q_{f, t+j}}{q_{f, t+j+1}} \frac{e_{t+j}}{e_{t+j+1}} p_{h, t+j+1}\right]$

And using the last period we get, from the perspective of a foreigner

$p_{h, t+k-1}=E\left[\beta \frac{U_{f}^{\prime}\left(c_{t+j+1}\right)}{U_{f}^{\prime}\left(c_{t+j}\right)} \frac{q_{f, t+j}}{q_{f, t+j+1}} \frac{e_{t+k-1}}{e_{t+k}} x_{h, t+k}\right]$

Calling the inflation rate, $\pi$, we use the following relation between the price levels and the inflation rate 
$\frac{q_{t+j+1}}{q_{t+j}}=\pi_{t+j+1}+1$

We also call the return on the exchange rate $\mathrm{r}_{\mathrm{e}}$ and use the relation

$\frac{e_{t+j}}{e_{t+j-1}}=r_{e, t+j}+1$

We also call the stochastic discount factor m, given by

$m_{t+j+1}=\beta \frac{U^{\prime}\left(c_{t+j+1}\right)}{U^{\prime}\left(C_{t+j}\right)}$

Using Equations 9, 10 and 11, replacing them in Equations 8 and 5, and equalizing equations 8 and 5 because the price of the asset in its home is the same for locals and foreigners we have the following relation between the stochastic discount factors

$m_{h, t+j+1}=m_{f, t+j+1} \frac{1+\pi_{h, t+j+1}}{1+\pi_{f, t+j+1}} \frac{1}{1+r_{e, t+j+1}}$

Note that if Purchasing Power Parity holds, we have

$\frac{e_{t+j+1}}{e_{t+j}}=\frac{1+\pi_{h, t+j+1}}{1+\pi_{f, t+j+1}}$

Or

$1=\frac{1+\pi_{h, t+j+1}}{1+\pi_{f, t+j+1}} \frac{1}{1+r_{e, t+j+1}}$

From where

$m_{h, t+j+1}=m_{f, t+j+1}$

Implying that, if Purchasing Power Parity holds, changes in exchange rates have no effect on the price of the index. 